
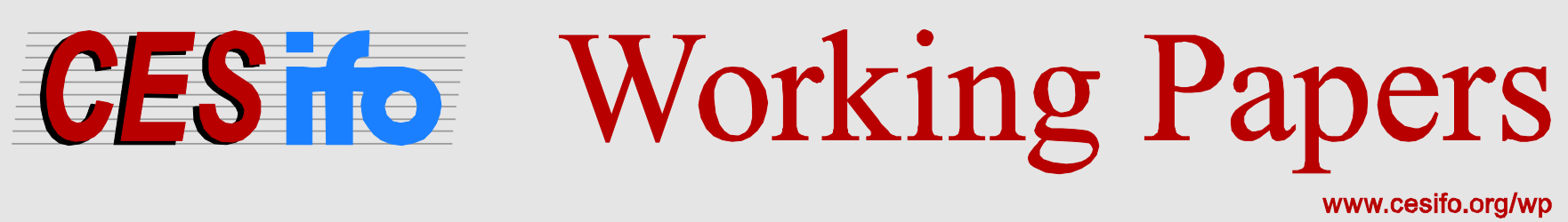

\title{
The Failure of ECB Monetary Policy from a Mises-Hayek Perspective
}

\author{
Gunther Schnabl
}

\author{
CESIFO WORKING PAPER NO. 6388 \\ CATEgORY 7: MONETARY POLICY AND INTERNATIONAL FINANCE \\ MARCH 2017
}

An electronic version of the paper may be downloaded

- from the SSRN website:

- from the RePEc website:

- from the CESifo website:

www.SSRN.com

Www.RePEc.org

www.CESifo-group.org/wp 


\title{
The Failure of ECB Monetary Policy from a Mises-Hayek Perspective
}

\begin{abstract}
The paper analyses the common European monetary policy based on a Mises-Hayek overinvestment framework, which is combined with the theory of optimum currency areas. It shows how since the turn of the millennium a too expansionary monetary policy contributed to unsustainable overinvestment booms in the periphery of the European Monetary Union, and more recently in Germany, dependent on the national fiscal policy stances. It is argued that the ECB's ultra-loose monetary policy as a crisis therapy puts a drag on long-term growth by conserving distorted economic structures. To preserve political stability a timely exit from the ultra-expansionary monetary policy is postulated.
\end{abstract}

JEL-Codes: E520, E580, F420, E630.

Keywords: Hayek, Mises, European Monetary Union, European Central Bank, monetary overinvestment theory, optimum currency areas, fiscal policy, asymmetric shocks, secular stagnation.

\author{
Gunther Schnabl \\ University of Leipzig \\ Grimmaische Straße 12 \\ Germany - 04109 Leipzig \\ schnabl@wifa.uni-leipzig.de
}

I thank Raphael Fischer und Taiki Murai for excellent research assistance. I thank the Friedrich August von Hayek-Foundation and Jackstädt Foundation for financial support. 
Since the early years, the European Monetary Union is encumbered by large imbalances. Up to the outbreak of the European financial and debt crisis in the year 2008 the countries in the southern and western part of the European Monetary Union experienced extraordinary boom phases, which were first understood as economic catch-up process and then turned out as unsustainable overinvestment and speculation booms. The economic development in Germany remained first sluggish, and seems to have turned into exuberance since the outbreak of the crisis in the periphery of the monetary union.

The paper analyses the causes and consequences of cyclical and structural imbalances within the European Monetary Union based on the monetary overinvestment theory by Mises (1912) and Hayek (1929). The overinvestment theory allows to identify too loose monetary policy as a reason for unsustainable overinvestment and speculation booms. To understand the heterogeneous economic development within the monetary union, the overinvestment theory is combined with the theory on optimum currency areas (Mundell 1961). In addition, the literature on the role of fiscal policies to cope with asymmetric shocks within a monetary union (De Grauwe 2016) is incorporated.

By doing so, the paper extends the literature, which regards financial exuberance and crisis as the outcome of too loose monetary policies (Adrian and Shin (2008), Brunnermeier and Schnabel (2014), Hoffmann and Schnabl (2008, 2011, 2014, 2016)) to the context of the European Monetary Union. It is a counter hypothesis to views, which see - based on Keynes (1936) - the European financial and debt crisis (euro crisis) as the outcome of a random shock (De Grauwe 2011). It also contradicts views that the gradual decline of growth rates in the industrialized countries including the member states of the European Monetary Union is due to a savings glut originating in ageing societies and an exogenous gradual fall of the marginal efficiency of investment (Bernanke 2005, Summers 2014).

By challenging the view that the crisis in the European Monetary Union can be resolved with the help of very expansionary monetary policy (Draghi 2014), a timely exit of the European Central Bank from zero and negative interest rates policy and comprehensive asset purchases is recommended. 


\section{Monetary Overinvestment Theories and Boom-and-Bust Cycles}

Based on the overinvestment theories of Mises (1912) and Hayek (1929) four types of interest rates can be distinguished (see Hoffmann and Schnabl 2011): First, the internal interest rate $i_{i}$ reflects the (expected) returns of (planned) investment projects. Second, the natural interest rate $i_{n}$ is the interest rate that balances supply of (saving) and demand for capital (investment). ${ }^{1}$ Third, the central bank sets the central bank interest rate $i_{c b}$. Fourth, the capital market rate $i_{c}$ is defined as the interest rate set by the private banking (financial) sector for credit provided to private enterprises. For simplicity we assume that the capital market rate equals the central bank rate.

\subsection{Boom and Bust in the Overinvestment Framework}

In the monetary overinvestment theory an economy is in equilibrium when the central bank rate equals the natural rate of interest. Then, planned savings are equal to investment. An economic upswing starts, when - for instance - an important innovation raises the internal interest rate of investment, bringing about a rise in investment at given interest rates. In the left panel of Figure 1 the investment curve shifts from $I_{i_{i_{1}}}$ to $I_{i_{i_{2}}}$, with the natural rate of interest rising from $i_{n_{1}}$ to $i_{n_{2}}$. If the central bank would lift the policy rate from $i_{c b_{1}}$ to $i_{n_{2}}$, assuming a perfect interest rate transmission to credit markets, planned savings and investment in the economy would stay in equilibrium $\left(S_{2}=I_{2}\right)$. If, in contrast, as in the left panel of Figure 1 the central bank does not raise the central bank rate $\left(i_{n_{1}}=i_{c b_{1}}=i_{c b_{2}}<i_{n_{2}}\right)$, too low interest rates will give rise to an unsustainable overinvestment boom. Holding policy rates too low (for too long) can be defined as type 1 monetary policy mistake.

1 Hayek (1929) and Wicksell (1898) had different concepts of the natural interest rate. According to Wicksell (1898), the deviation of the central bank and capital market interest rates from the natural rate of interest disturbs the equilibrium between ex-ante savings (S) and investment (I) plans. This leads to inflationary (I $>S$ ) or deflationary pressure $(\mathrm{S}>\mathrm{I})$. During a credit boom the supply of goods cannot satisfy the additional demand for goods at given prices, which leads to inflation. Mises (1912) and Hayek (1929) explained business cycles by the deviation of the central bank (capital market) interest rate from the natural rate of interest. Hayek emphasized the importance of the intertemporal alignments of plans of producers and consumers to explain overinvestment as a mismatch between the production structure and consumer preferences. The natural interest rate is the interest rate which aligns saving and consumption preferences with the production structure over time. 
To market participants a rise in credit to the private sector at constant interest rates signals that saving activity of households has increased. Additional credit-financed investment projects aim to satisfy the expected rise in future consumption. As planned household savings did not increase, an unsustainable disequilibrium between ex-ante saving and investment $S_{2}<I_{2}$ at $i_{c_{2}}<i_{n_{2}}$ is created. Additional investments of some enterprises lead to further investments of other enterprises, which accelerates the cumulative upward process. As soon as capacity limits are reached and free capacities in labor markets are fully used, wages and prices rise.

Price increases signal to enterprises additional profits and therefore trigger further investments. There are spill-over effects to financial markets. Stocks are attractive because of low interest rates on bank deposits. Stock prices increase, also encouraged by higher (expected) profits of enterprises. When stock prices move upward, speculation may set in, providing extra momentum such that "the symptoms of prosperity themselves finally become [...] a factor of prosperity" (Schumpeter 1912: 226). As the owners of stock and real estate feel richer, consumption is stimulated via the wealth channel, which adds to inflationary pressure.

\section{Figure 1: Overinvestment Boom and Crisis}
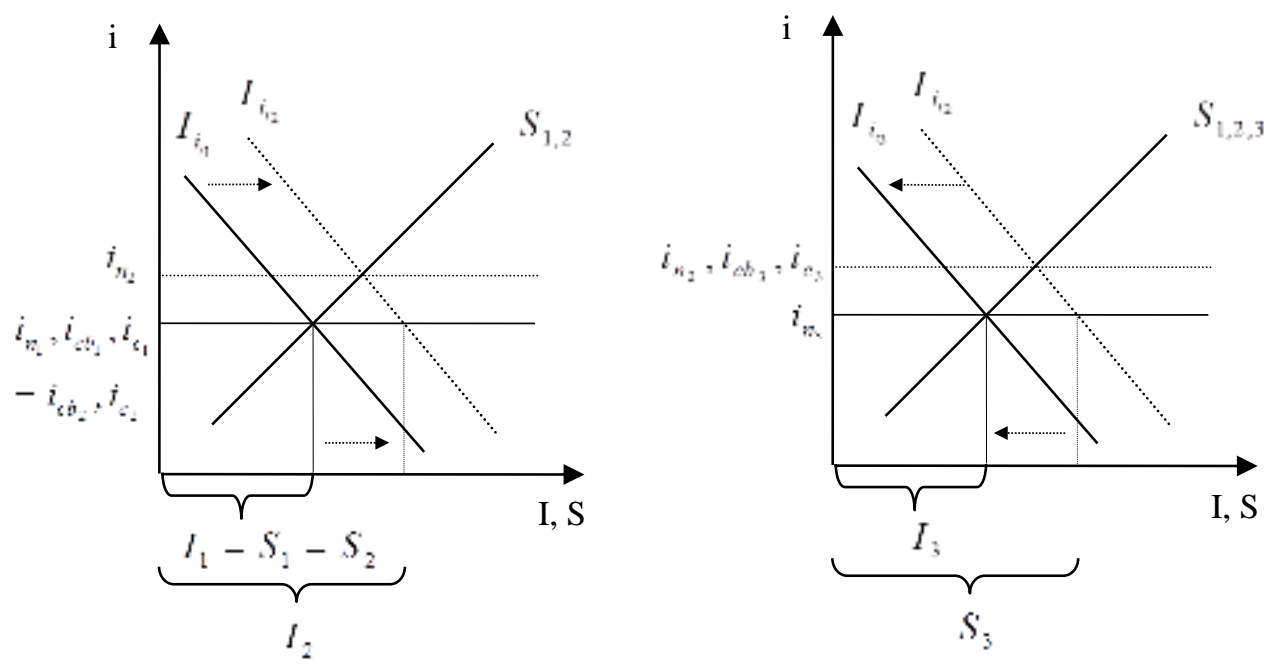

The turn-around occurs, when the central bank increases the central bank rate to contain inflationary pressure (Mises, 1912; Hayek, 1929; 1937). The benchmark for the profitability of past and future investment projects is lifted. Investment projects with an internal interest rate below the risen central bank and capital market interest rates turn out to be unprofitable. As first enterprises are forced to dismantle investment projects, the investment activity of other enterprises will stagger. The investment curve shifts back from $I_{i_{i_{2}}}$ to $I_{i_{i_{3}}}$ (see right panel of Figure 1). As stock (and other asset prices) start to fall, the equity of banks and enterprises falls, 
bringing about a credit crunch and further disinvestment. A cumulative downward process sets in. Wages fall and unemployment grows.

The monetary overinvestment theories assumed that during the downturn the central bank holds the interest rates above the natural interest which can be labelled monetary policy mistake of type 2 . The high central bank interest rate comes along with a high capital market interest rate and thus a tightening of credit during the crisis. The right panel of Figure 1 shows that when the policy interest rate is held above the natural interest rate $\left(i_{c b_{3}}=i_{c_{3}}>i_{n_{3}}\right)$, ex-ante saving is higher than investment $\left(S_{3}>I_{3}\right.$ ). The recession is aggravated.

\subsection{Asymmetric Central Bank Crisis Management}

Figure 2: Short-Term Interest Rates: US, Japan and Germany/Euro Area

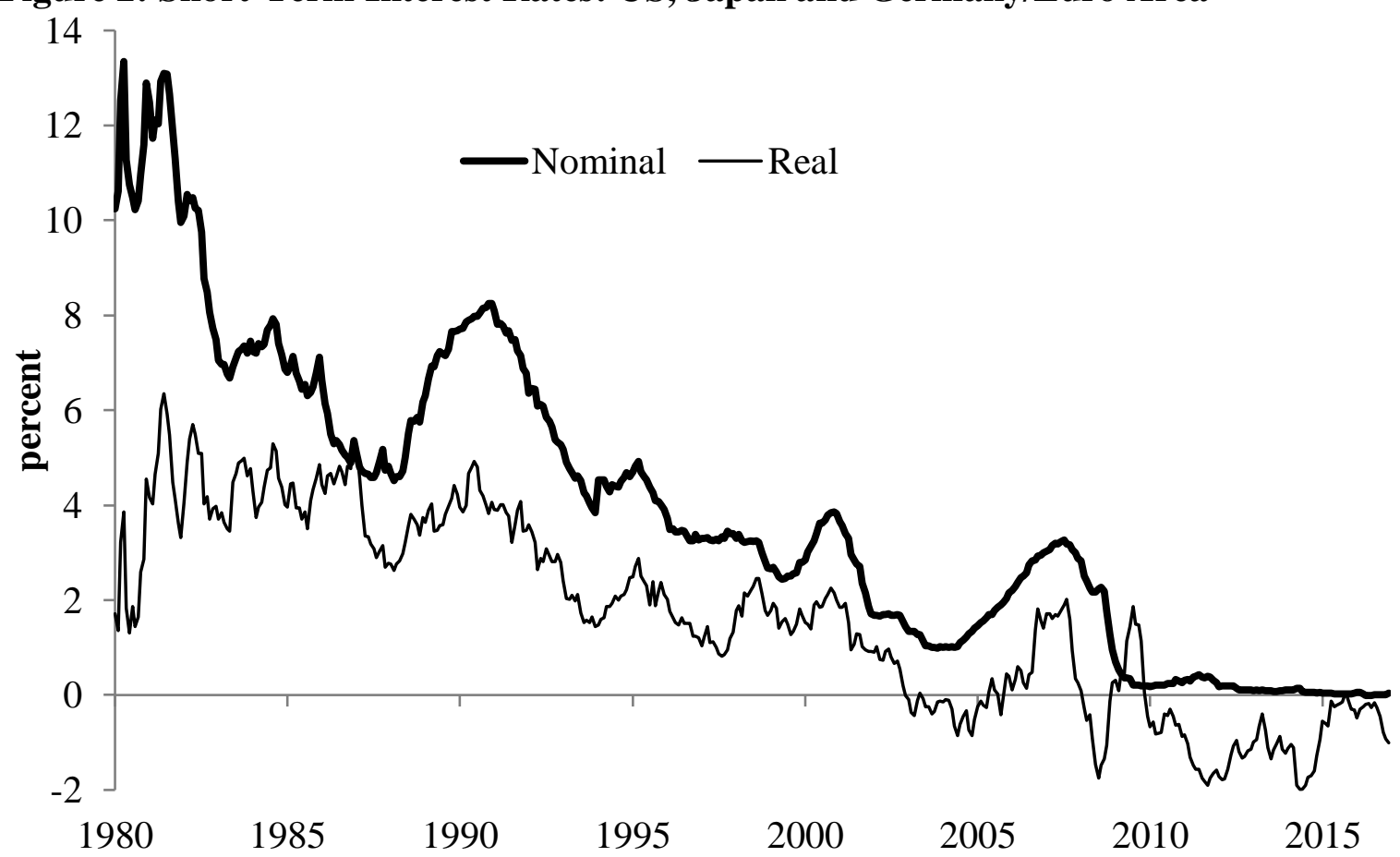

Source: International Monetary Fund (IMF). Arithmetic averages. Money market rates: Germany up to 1998.

Hoffmann and Schnabl $(2008,2011,2014,2016)$ stress with respect to the monetary policy making of the large central banks since the mid 1980s that central bank monetary policy mistakes were not made symmetrically as assumed by Mises (1912) and Hayek (1929). Instead, since the mid 1980s, the large central banks have set policy interest rates low during periods of economic upswing, thereby fueling overinvestment and unsustainable booms in financial markets. This corresponds to type 1 monetary policy mistakes. In contrast, during (financial) 
crises, interest rates were cut decisively to prevent type 2 monetary policy mistakes. With the so-called 'Jackson Hole consensus', central bankers claimed that central banks do not have sufficient information to recognize bubbles, but should react decisively to financial turmoil (Blinder and Reis 2005). The consequence of such asymmetric monetary policy crisis management patterns has been a cyclical downward-trend in nominal and real interest rates in the large economies as shown in Figure 2.

With interest rates approaching the zero-bound (in Japan since 1999 and the US and euro area since 2008), large-scale asset purchases have gradually expanded central bank balance sheets (Figure 3). Government bond purchases of central banks (i.e. unconventional monetary policies) have pushed down the interest rate at the long end of the yield curve. Up to the present the gradual exit from very expansionary monetary policies (tapering) has remained limited to the Federal Reserve, which has reduced asset purchases to zero and is only slowly lifting interest rates.

Figure 3: Central Bank Assets (Percent of GDP): Japan, US, Euro Area

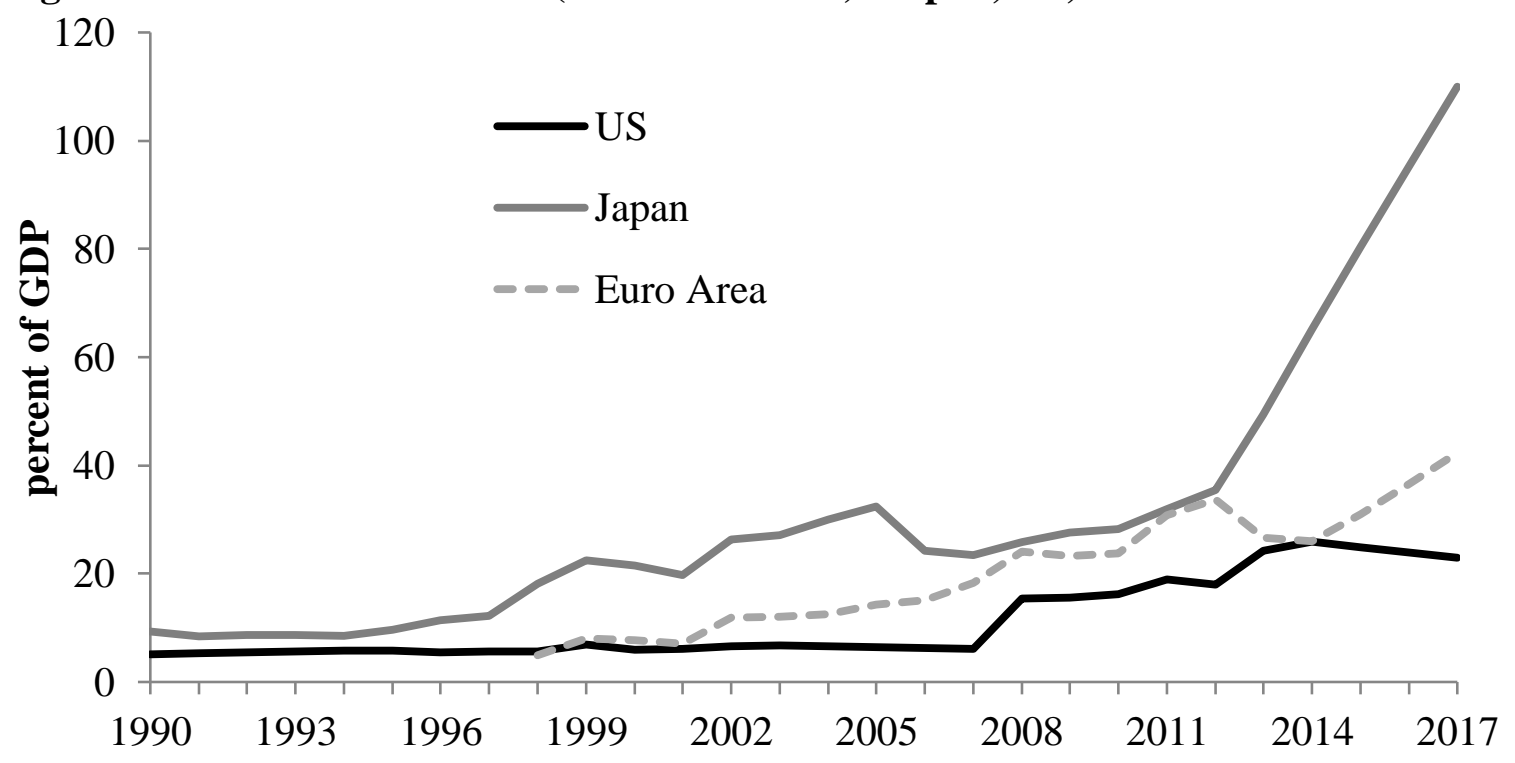

Sources: World Economic Outlook (WEO), European Central Bank and Eurostat. 2016 und 2017 are projections.

As national monetary policy decisions are interconnected via the exchange rates (Hayek 1937), the global interest rate path can be assumed to have been an important side condition for the monetary policy decisions of the European Central Bank. A tight monetary policy of the European Central Bank relative to other large central banks would have been costly, because 
the resulting euro appreciation would have slowed down growth, in particularly in countries with historically weak currencies.

\section{Reasons for the European Financial and Debt Crisis}

Although the institutional framework of the European Central Bank was modelled after the price stability-oriented German central bank (Deutsche Bundesbank), in the course of time the way of monetary policy making in the EMU gradually diverged towards the model as it prevailed in the southern and western European countries prior to the European Monetary Union. This caused boom and bust in different parts of the monetary union in different periods of time.

\subsection{The Institutional Framework of Common European Monetary Policy Making}

Prior to the European Monetary Union two different (and intertwined) growth and central bank models in Europe prevailed. In Germany and some smaller northern European countries such as Austria and the Netherlands had comparatively high saving rates, high investment and export-driven growth. The northern European growth model depended on price stabilityoriented central banks, which ensured low real interest rates as a prerequisite for buoyant investment. Central bank independence (as in the case of the Deutsche Bundesbank) went along with fiscal discipline. Governments had to finance expenditures via tax revenues. As the smaller northern European countries pegged their exchange rates more or less tightly to the German mark, the German central bank was in the center of the northern European growth model.

In contrast, in the southern and western part of Europe, the growth models were oriented towards consumption and government expenditure. An important source of public financing were the central banks, which were subject to guidance by the governments. This implied higher inflation rates than in the northern part of Europe. The resulting depreciations of the currencies of the southern and western European countries against the German mark provided additional aggregated demand stimulus. For Germany and its smaller neighboring countries, these beggarthy-neighbor policies were economically and politically acceptable ${ }^{2}$, because they got access to

2 As Deutsche Bundesbank did depreciate the German mark in response to the depreciation of the southern European currencies, destabilizing competitive depreciations were prevented. 
the southern and western European markets. This helped to realize economies of scale in industrial production.

The upshot is that the pre-EMU European growth was based on buoyant industrial production in the northern part of Europe, which generated sufficient productivity gains to realize real wage increases in all parts of the European (Economic) Community. The real income gains for citizens in all western European countries enhanced the political acceptability for the deepening of the European integration process. The resulting gradual implementation of the four freedoms - i.e. free movement of goods, services, capital and labor - created additional growth and welfare gains (see Freytag and Schnabl 2017).

As the high inflation experience of the 1970s had proven to deliver high unemployment and low growth, in the early 1990s the German central bank model became with the Maastricht Treaty implemented for the whole European Union. According to Art. 127 TFEU "the primary objective of the ESCB shall be to maintain price stability. Without prejudice to the objective of price stability, the ESCB shall support the general economic policies in the Union with a view to contributing to the achievement of the objectives of the Union as laid down in Article 3 of the Treaty on European Union. At a first glance, the provisions on macroeconomic convergence in the European (Monetary) Union led to an unprecedented degree of low inflation in Europe, as inflation rates in all EMU member states converged towards the German benchmark (see Figure 4).

The Achilles heel of the monetary union became the high degree of heterogeneity of the member states. Mundell (1961) had argued that an optimum currency area had to consist of homogenous countries with a low likelihood of asymmetric shocks, i.e. with synchronized business cycles. A high likelihood of asymmetric shocks within a monetary union - as it seemed to be given between the southern and northern European countries - would necessitate a high degree of wage flexibility and/or labor mobility. As tight labor market regulations prevent wage flexibility in most European countries ${ }^{3}$, fiscal policies could be seen as mechanism to cope with asymmetric shocks and idiosyncratic business cycles.

De Grauwe (2016) shows that idiosyncratic business cycles can be addressed either by a centralized fiscal policy or by coordinated anticyclical fiscal policies on a national level. For

3 The Baltic countries have, however, achieved a high degree of labour market and fiscal flexibility. 
instance, if France is in a boom and Germany in a recession, a one-size-fits-all monetary policy (which targets the average inflation of France and Germany) would set a too low interest rate for France. This would contribute to even higher inflation. The interest rate would be too high for Germany, which would further aggravate the recession. The one-size-fits-all monetary policy would be inefficient for both parts of the monetary union.

\section{Figure 4: Inflation Convergence in Western Europe}

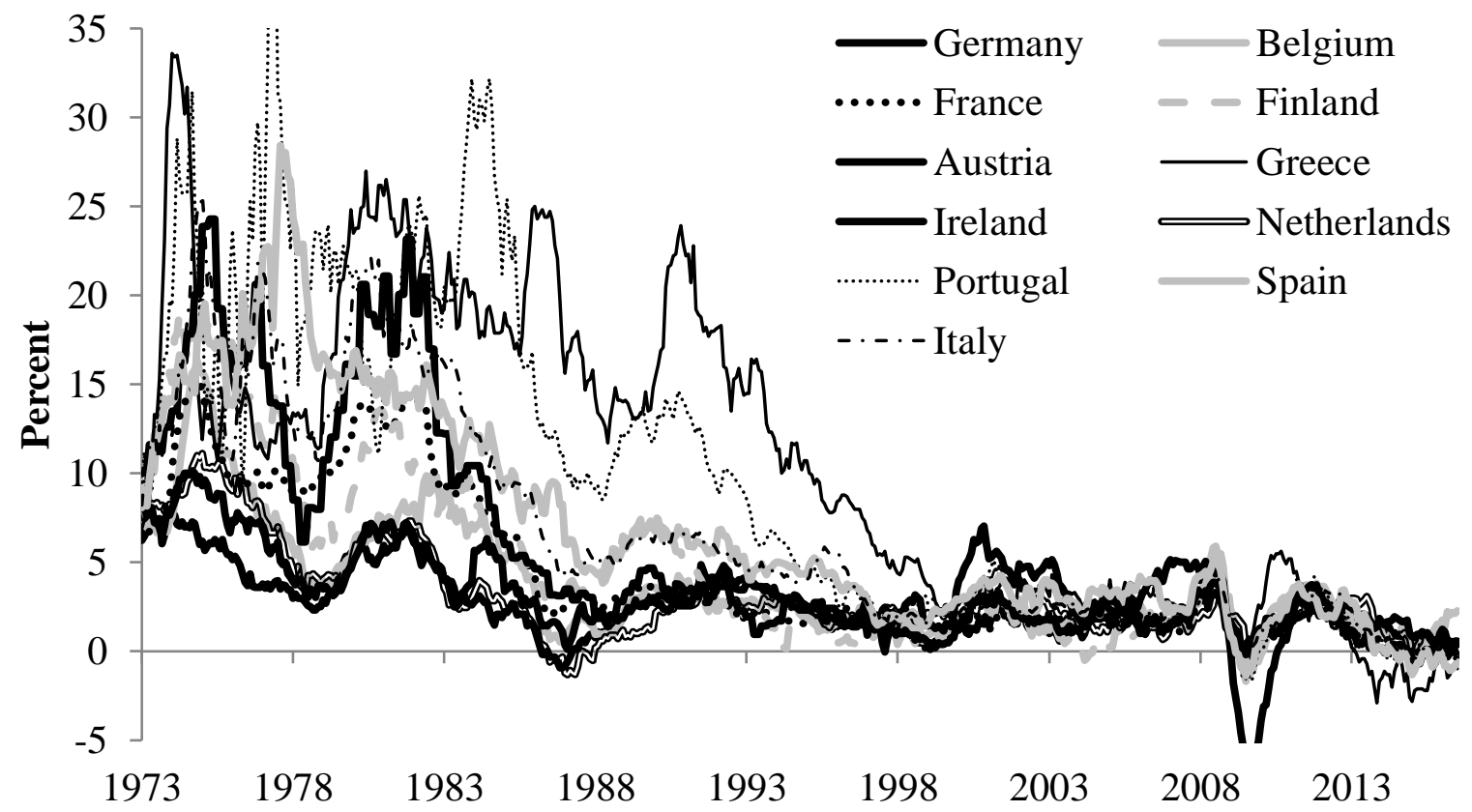

Source: IMF.

A common centralized fiscal policy would help to automatically absorb the asymmetric shock, as higher tax revenues (lower spending for unemployment) in France would be equilibrated by lower tax revenues (higher spending for unemployment) in Germany. Alternatively, with fiscal policy making remaining organized on a national level, fiscal policies could ensure the efficiency of monetary policy, if they would be restrictive in France and expansionary in Germany to synchronize the business cycles in the monetary union (De Grauwe 2016). ${ }^{4}$ Yet, the institutional setting of the European Monetary Union did not stipulate a specific role of fiscal policies to cope with asymmetric shocks. The Maastricht criteria put a limit on general government budget deficits (3\% of GDP) and the stock of general government debt (60\%), but did not install a mechanism to prevent or balance heterogeneous economic development.

\footnotetext{
4 With the business cycle being inversed at a later point of time, the mechanism is inversed as well.

5 According to Art. 126 TFEU “(1) Member States shall avoid excessive government deficits. (2) The Commission shall monitor the development of the budgetary situation and of the stock of government debt in the Member States with a view to identifying gross errors. In particular it shall examine compliance with budgetary discipline..."
} 


\subsection{A Mises-Hayek Based Explanation of the European Financial and Debt Crisis}

This put stage for the European financial and debt crisis, as the combination of the ECB's expansive monetary policy since the year 2000 and uncoordinated fiscal policies on a national level created the breeding ground for an overinvestment boom in the periphery of the European Monetary Union. The European Central Bank cut the main refinancing rate strongly in response to the bursting dotcom bubble (staring from March 2000) from 3.75\% in May 2001 to $1 \%$ in June 2003 (see Figure 4). Given that the key interest rate fell to a historical low, the likelihood increased that the central bank rate was cut below Hayek's natural interest rate as in the left panel of Figure $1 .^{6}$

\section{Figure 4: ECB Main Financing Rate and Size of Balance Sheet}

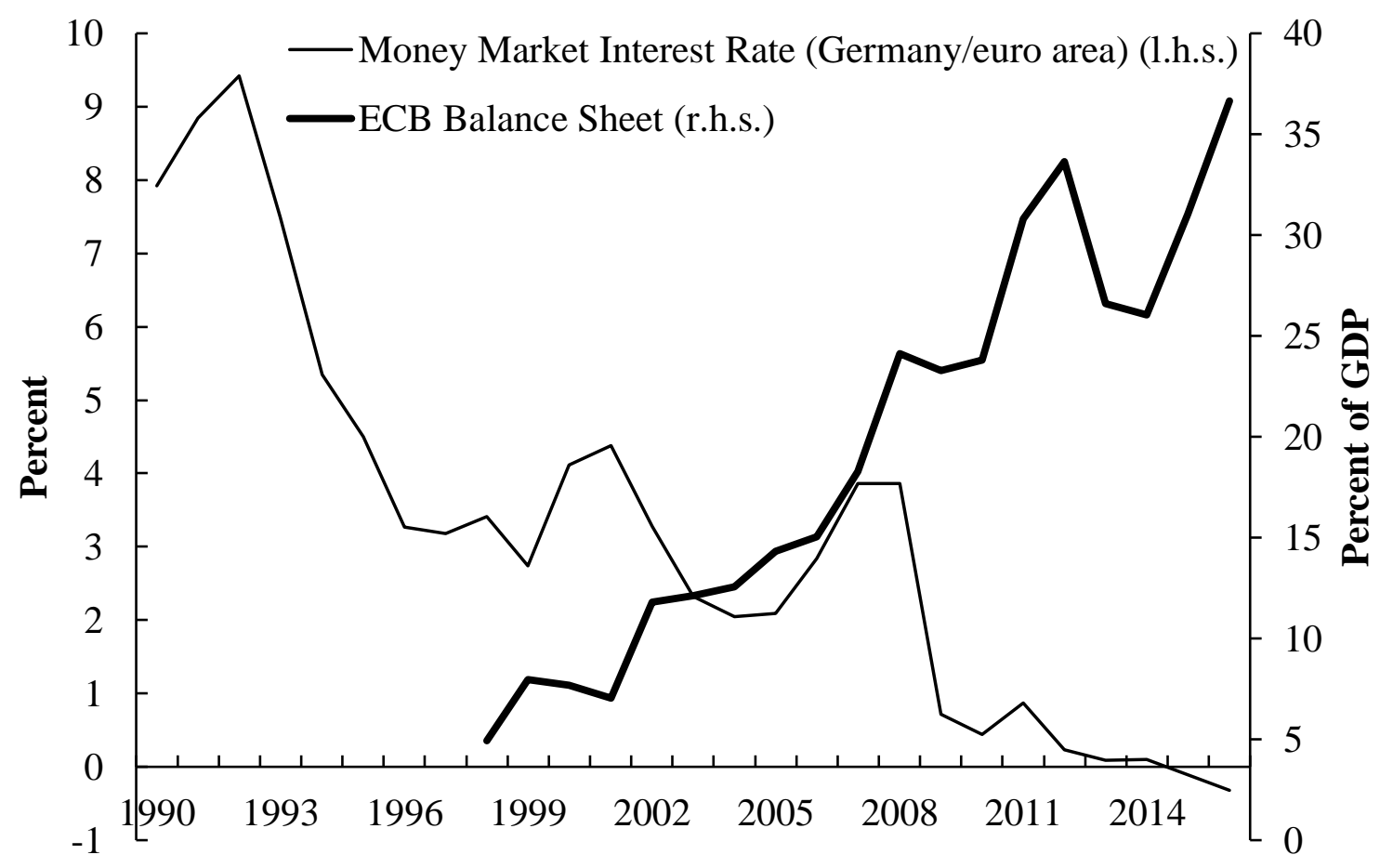

Sources: World Economic Outlook (WEO), European Central Bank and Eurostat. Money market rate: Germany up to 1998.

This is suggested by Figure 6 which uses the Taylor (1993) rule to define a target value for the main refinancing rate of the European Central Bank under consideration of the consumer price

6 In the US, similar interest rate cuts nurtured a speculation boom in the real estate market, which led into the subprime crisis. 
inflation and the output gap. ${ }^{7}$ Negative values indicate a too low central bank interest rate, which generates inflationary pressure. Positive values indicate a too high central bank interest rate, which leads to deflationary pressure. According to this Taylor-benchmark the short-term interest rate set by the European Central Bank was for whole euro area below target at the start of the European Monetary Union and became increasingly too low afterwards. For the later euro area crisis countries (Greece, Ireland, Italy, Portugal, Spain), which experienced a boom since the turn of the millennium, the interest rate set by the ECB was much too low up to the crisis. In contrast, for Germany the monetary conditions set by the ECB were slightly too tight up the year 2004 and then became slightly too loose.

Figure 6: Euro Area Money Market Rate Relative to Taylor-Target Rate

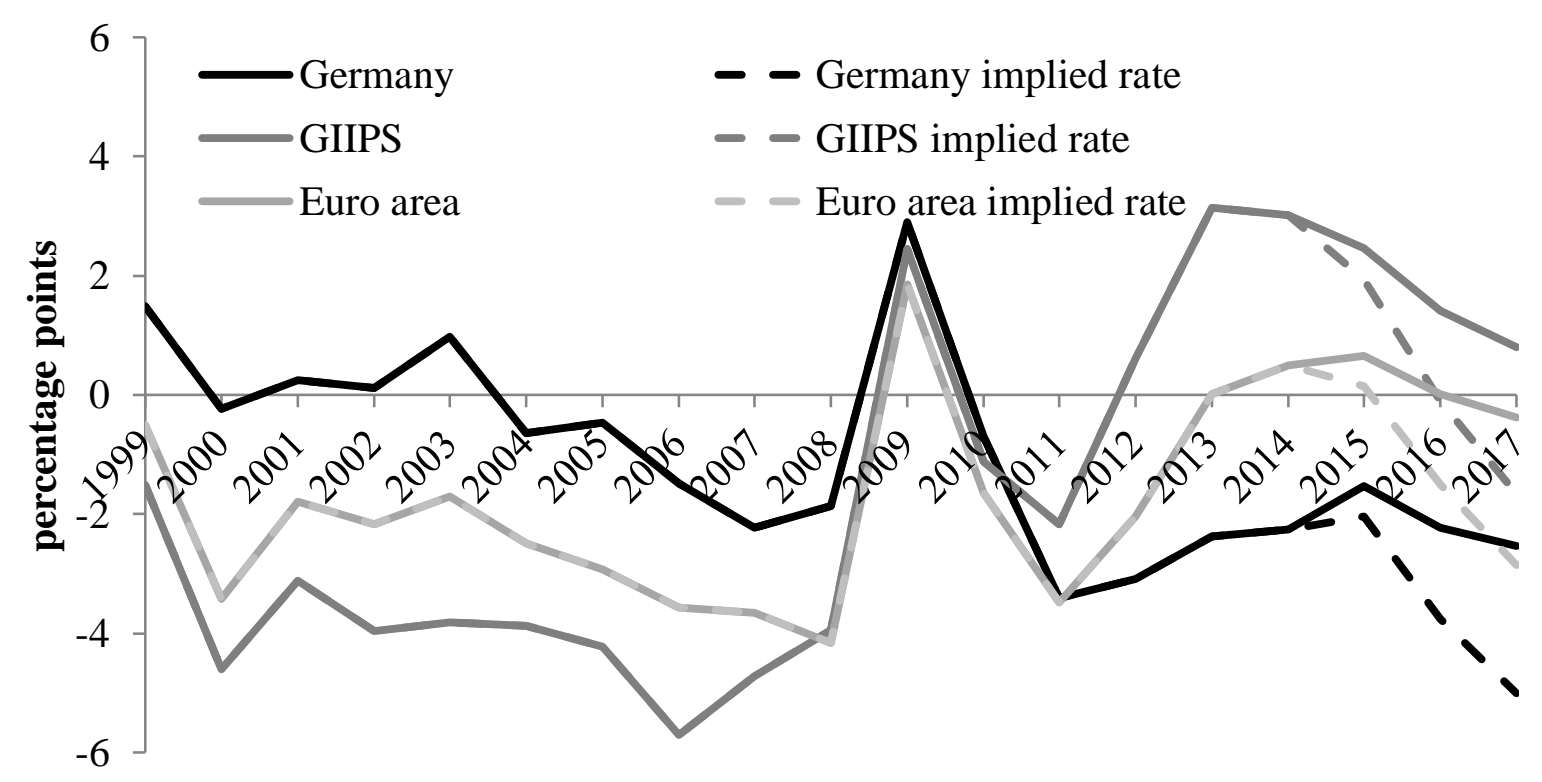

Source: OECD Economic Outlook, ECB and National Statistics Offices. The target interest rates are calculated following Taylor (1993) rule based on national inflation rates and output gaps. The lines indicate the deviations of the ECB main financing rate from the Taylor target rates calculated for the euro area and single countries. Positive values indicate the ECB main refinancing rate to be above the national optimal target rate (too tight). Negative values indicate the ECB main refinancing rate to be below the national optimal target rate (too loose). For the GIIPS (Greece, Ireland, Italy, Portugal, Spain) countries an arithmetic average is calculated. After the main refinancing rate has reached the zero bound, the ECB embarked on extensive unconventional monetary policy measures including large government bond purchases. The implied rates represent an ECB main refinancing rate which is augmented by the unconventional monetary policy measures taken after the main refinancing rate had reached the zero bound in 2014. For this purpose it is assumed that the semi-interest rate elasticity of a balance sheet expansion is about 8 , i.e. a balance sheet expansion by about $8 \%$ leads to a decline

7 The Taylor rule as a tool to provide an appropriate benchmark for central bank interest rate setting should be treated with caution, because the transmission of monetary policy making towards consumer price inflation has become increasingly disturbed since the mid 1980s (see Baur, Gerstenberger and Schnabl 2017). Incorporating the effects of monetary policy on asset prices would deliver even higher Taylor rule target rates. 
in the main refinancing rate by 1 percentage point. (This corresponds to the semi-average balance sheet elasticity of the interest rate between 1999 to 2013.) The values for 2016 and 2017 are based on forecasts.

The asymmetric effect of the one-size monetary policy in different parts of the EMU as indicated by the Taylor rule has been widely attributed to the interest rate convergence process in southern and western Europe (see for instance Sinn und Wollmershäuser 2013): Because the southern and western European countries had entered the European monetary union, financing conditions at all maturities converged from high levels towards Germany's low level. As this convergence process went along with a macroeconomic stabilization process, the high growth rates of the EMU periphery countries were regarded to be fundamentally justified. The resulting sharp decline of the interest rate is assumed to have boosted growth.

The EMU convergence scenario hypothesis neglects, however, the fact that at the same time similar credit booms took place in non-EMU countries such as Island and many central and eastern European countries. Therefore, to explain different inflation rates and growth rates in different parts of the European Monetary Union and beyond, the role of fiscal policies in counter-steering or amplifying the (potential) credit booms in different parts of the European Monetary Union has to be considered (Schnabl and Wollmershäuser 2013). In Germany, the expansionary monetary policy of the ECB after the turn of the millennium was combined with a tight fiscal policy stance. In the late 1990s the high costs of the German unification had brought the sustainability of the generous German welfare state to its limits. Unemployment had increased strongly during the 1990s.

Given that by 1999 the general government debt had reached the Maastricht limit of $60 \%$ of $\mathrm{GDP}^{8}$, the government felt forced to implement fundamental reforms. The German government curtailed government expenditure (see Figure 6), in particular by restraining wage increases in the public sector. As labor markets were deregulated and social security benefits were streamlined, the wage austerity spilled over to the private sector. Investment declined as domestic business perspectives turned gloomy. The tight fiscal policy stance kept inflation low and the real interest rate relatively high, thereby preventing an overinvestment boom despite monetary expansion.

\footnotetext{
8 After the introduction of the euro the general government budget deficit fell below the -3\% of GDP Maastricht
} limit. This was partially due to the reforms, which slowed down growth and thereby reduced tax revenues. 
By dampening domestic economic activity, the combination of a loose monetary policy with a tight fiscal policy boosted instead capital outflows from Germany ${ }^{9}$ from the year 2001 onwards. In the periphery countries inside and outside the euro area the capital inflows boosted investment, growth and inflation. Declining real interest rates triggered an overinvestment boom as in the left panel of Figure 1, which came along with speculation in real estate and stock markets. The resulting increase of tax revenues induced a dramatic increase in government expenditures, which added further momentum to the exuberance. Figure 6 shows that the expenditure paths of the later euro area crisis countries were much more expansionary than in Germany.

\section{Figure 6: Diverging Spending Paths of Germany and EMU-Crisis Countries}

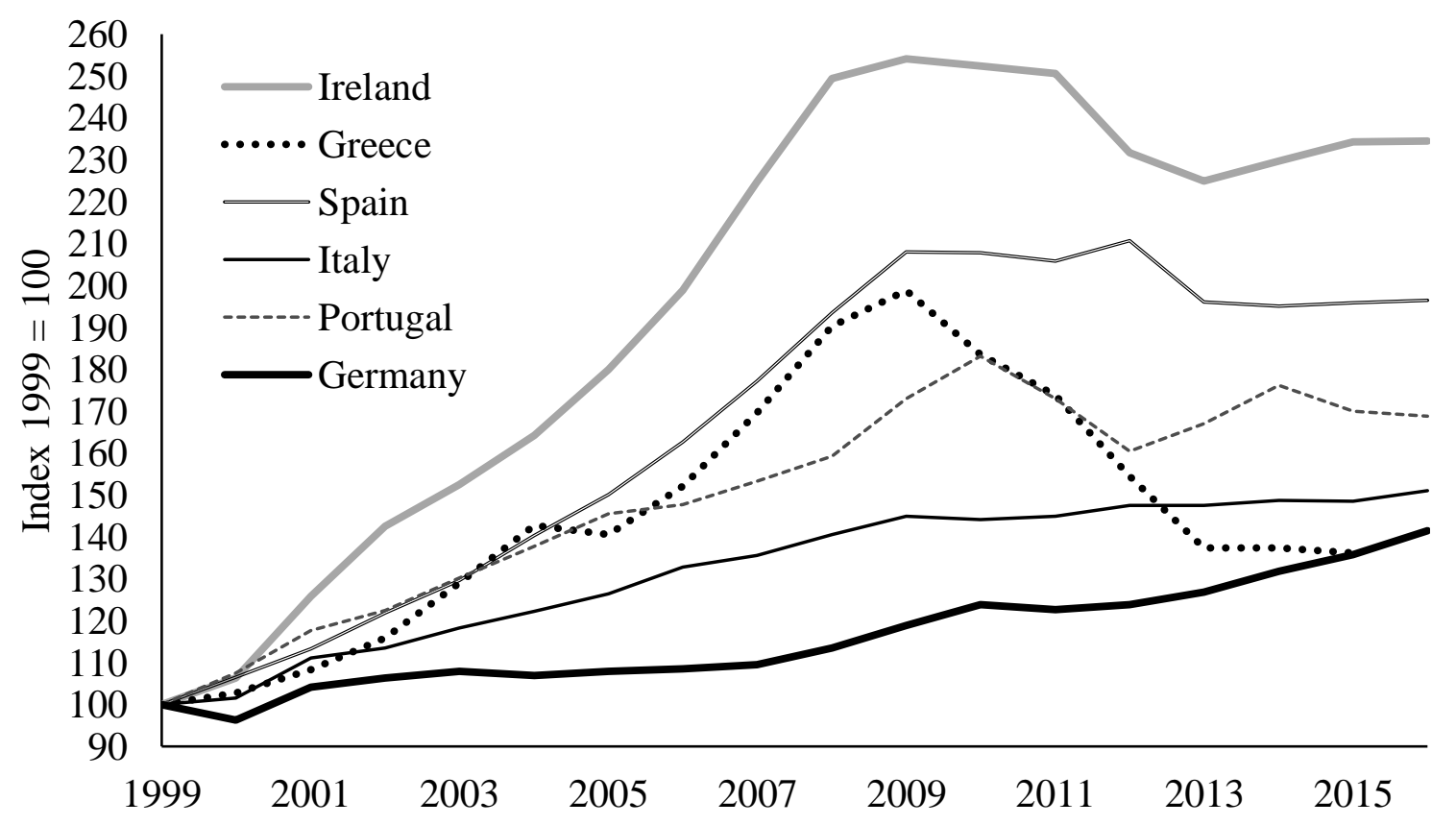

Source: IMF: WEO. General government expenditure in euros indexed to 100 in 1999.

In short, the divergence of fiscal policy stances in the euro area caused in the face of a too loose monetary policy a kind of "waterbed effect": the liquidity issued by the European Central Bank as a crisis therapy for the whole euro area was one-sidedly pushed to the periphery causing overinvestment and speculations booms. The growing imbalances within the European

\footnotetext{
9 As the reduction of future pensions was paired with incentives for private provisions for retirement, savings of the private sector increased. The resulting dramatic rise of aggregate savings over investment contributed to the significant rise in capital outflows.
} 
Monetary Union became reflected in growing current account imbalances as shown in Figure 7. Real wage increases far beyond productivity gains led to a real appreciations of the euros of the later crisis countries and thereby growing current account deficits. This process was matched by a real depreciation of the German euro and thereby a growing current account surplus of Germany. ${ }^{10}$

\section{Figure 7: Intra-EMU Current Account Imbalances}

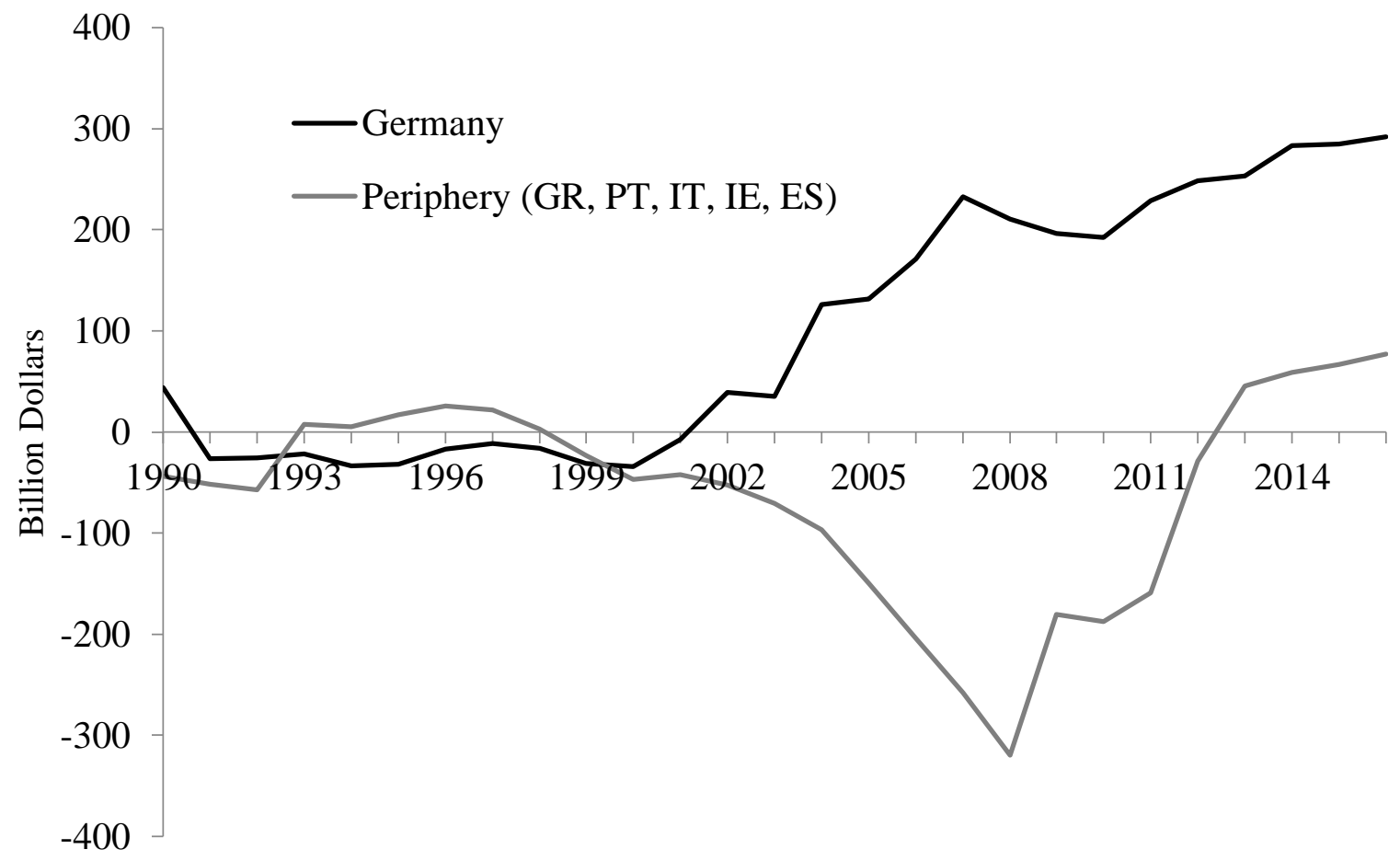

Source: IMF: WEO.

The exuberance was tilted either towards stock and real estate bubbles (Spain and Ireland) or towards public consumption booms (Greece, Portugal). As the overinvestment/speculation booms inflated the tax revenues of the southern and western euro area countries, the Maastricht fiscal criteria failed to indicate unsustainable government expenditure. Public spending in the later crisis countries could strongly increase without increasing the public debt levels (Ireland and Spain) or with budget deficits remaining below the Maastricht benchmark (Greece and Portugal). With sharply increasing tax revenues being mainly driven by the ECB`s low interest rate policy and the large credit provision from Germany, the unsustainable increases of government expenditures became only visible after the economic turn-around in form of sharply increasing public debt levels.

10 In Germany, real wage increases were lagging behind productivity increases in the respective time period. 
The booms peaked in the year 2008, when after the break-out of the US subprime crisis the mood in international financial markets changed. Since the year 2005 - as in the overinvestment theory - both the European Central Bank and the Federal Reserve had stepwise increased interest rates. With German commercial banks having realized substantial losses in the subprime market, they stopped exporting capital to the periphery countries inside and outside the euro area. This constituted an additional credit tightening beyond the tightening of the ECB monetary policy. With credit-financing for the overinvestment booms drying out, the European periphery countries were pushed into a severe crisis as in the right panel of Figure 2.

\section{$4 \quad$ Implications of Monetary Policy Crisis Management}

With real wages levels having risen above productivity levels, the resulting European financial and debt crisis necessitated the ad hoc build-up of comprehensive rescue mechanisms such as multilateral rescue packages, the European Financial Stability Facility (EFSF), the European Financial Stability Mechanism (ESM) and an unprecedented monetary expansion of the ECB balance sheet. Within a heterogeneous European Monetary Union, the monetary policy rescue measures of the European Central Bank had different effects in the euro area crisis countries and Germany. Whereas the southern European crisis countries remain stuck in crisis, now Germany is experiencing an overinvestment and speculation boom. Both developments are amplified in both parts of the EMU by pro-cyclical fiscal policies.

\section{4a. Lasting Stagnation and Zombification in the Crisis Countries}

In response to the crisis the European Central Bank cut interest rates to zero and is strongly expanding its balance sheet by extensive - mainly government - bond purchases (see Figure 4). Hayek (1933: 20) argued that "to combat the depression by a forced credit expansion is to attempt to cure the evil by the very means which brought it about. " The low cost-liquidity provisions via the European Central Bank to the European crisis countries can be assumed to have paralyzed growth in the southern European crisis countries, because Schumpeter's (1912) creative destruction is prevented and distorted economic structures are conserved. As Hayek put it (1931: 98): "if voluntary decisions of individuals are distorted by the creation of artificial demand, it must mean that part of the available resources is again led into a wrong direction and a definite and lasting adjustment is again postponed." 
The negative impact of monetary policy crisis management on investment and growth in the crisis countries comes via the banking sectors, which are bailed out by credit provision of the national central banks at eased collateral requirements ${ }^{11}$. Within the Eurosystem the resulting additional liquidity requirements of the national central banks are provided by the European Central Bank. The national banking sectors are in addition stabilized by the large-scale government bond purchases of the European Central Bank ${ }^{12}$, as euro area banks are holding increasing amounts of government bonds. Furthermore, the Agreement on Net Financial Assets (ANFA) allowed since November 2014 for regional monetary policy rescue measures, as national central banks of the Eurosystem were allowed to purchase bonds of their own governments. The structure of the ANFA purchases is strongly tilted toward government bond purchases of southern euro area countries. The volume had risen to 560 billion euros by February 2015. ${ }^{13}$

With the national central banks being part of the Eurosystem, the intra-euro area rescue measures became reflected in the TARGET2 balances of the European Central Bank. TARGET2 (Trans-European Automated Real-time Gross Settlement Express Transfer System) is a real-time gross settlement system for payments within the euro zone, which is used to clear cross-border transfers in the euro area. Before the European financial and debt crisis the national central banks' positions in the TARGET2 system were widely balanced, because private capital flows were matched by respective payment flows resulting from goods markets transactions. ${ }^{14}$

11 As, for instance, made possible by the so-called Emergency Liquidity Assistance (ELA).

12 After the European Central Bank had cut interest rates towards zero it embarked on several bond purchase programs such as the Securities Markets Program (SMP, May 2010 to September 2012, 211 billion euros) and the Outright Monetary Transactions Program (OMT, from July 2012), which was up to today not activated, but included the promise to undertake "whatever it takes" to keep the euro area together. Two Covered Bond Purchase Programs (CBPP1: 60 billion euros from July 2009 to June 2010, CBPP2: 16.4 billion euros from Nov 2011 to October 2012) expanded the ECB balance sheet. In January 2015, the Asset Purchase Program (APP) was announced, which included the previously launched Covered Bond Purchase Program 3, the Assetbacked Securities Purchase Program (ABSPP) and the Public Sector Purchase Program (PSPP). The APP allowed purchases of government and corporate sector bonds of up to 80 billion euros per month. Up to March 2017 the aggregated purchase volume was 1740 billion euros. The purchase program was extended with a smaller scale of 60 billion euros per month to December 2017 bringing the overall volume of (government) bond purchases to 2250 billion euros. The purchase programs not only held the money market rate at zero, they also depressed the interest rates at the longer end of the yield curve. This significantly reduced the interest rate burden for over-indebted governments in the euro area, which can be seen to be against Art. 127 of TFEU.

13 ANFA is equivalent to a regional monetary policy within a one-size monetary policy framework.

${ }^{14}$ Note that according to the balance of payment identity, in the absence of public capital flows the current account is equivalent to the financial account with inversed sign. Given public capital flows, the sum of private and public capital flows has to match the current account balance with inversed sign. 
For instance, German (Greek) capital exports ${ }^{15}$ (capital imports) corresponded to payments receipts (payments) for German goods sales (Greek goods purchases).

With the outbreak of the crisis, current account deficits of the periphery countries persisted (Figure 7), whereas German banks stopped providing credit to the commercial banks in the periphery countries. As banks in the crisis countries continued to finance the payments flows for goods transactions, they had to refinance at their national central banks, which themselves refinanced at the European Central Bank. At the same time the payments received by German export enterprises were deposited via German commercial banks at the German central bank. The upshot is that the central banks of the crisis countries became a debtor versus the European Central Bank and the German central bank became a creditor to the European Central Bank. This is reflected in a divergence of the TARGET2 balances of the national central banks at the European Central Bank (Figure 9). The yearly changes of these balances are equivalent to the public capital flows across intra-EMU borders.

When current account deficits declined and capital flight from the crisis countries increased, this led to capital shortages of the commercial banks of the crisis countries, which were compensated by credit from the national central banks at eased collateral conditions. With this capital being deposited in German banks, the deposits of German commercial banks at Deutsche Bundesbank increased. Thus, the growing divergence of the TARGET2 balances became increasingly driven by capital flight from the euro area crisis countries to Germany. As shown in Figure 9 a small number of northern European countries, - i.e. Germany, Netherlands, Luxemburg and Finland - provide credit within the TARGET2 system. Most other euro area countries, in particular the crisis countries, are recipients of this public quasi-credit system.

The liquidity provision for the crisis countries prevented on the peak of the crisis a type 2 monetary policy mistake, i.e. a too tight monetary policy stance for the crisis countries. However, as the public liquidity provision via the TARGET2 system persists and ECB government bond purchases holdings to be further extended, the central bank seems to have pushed the capital market interest rate again below the natural interest. In Figure 6 this is indicated by the implied interest rate being below benchmark for the crisis countries recently. The transmission of these monetary policy rescue measures to negative growth effects is via the banking sectors, which suffer from declining profits for three main reasons (Schnabl 2015).

15 I.e. credit provided by a German bank to a Greek bank. 
Figure 9: TARGET2 Imbalances within the European Monetary Union

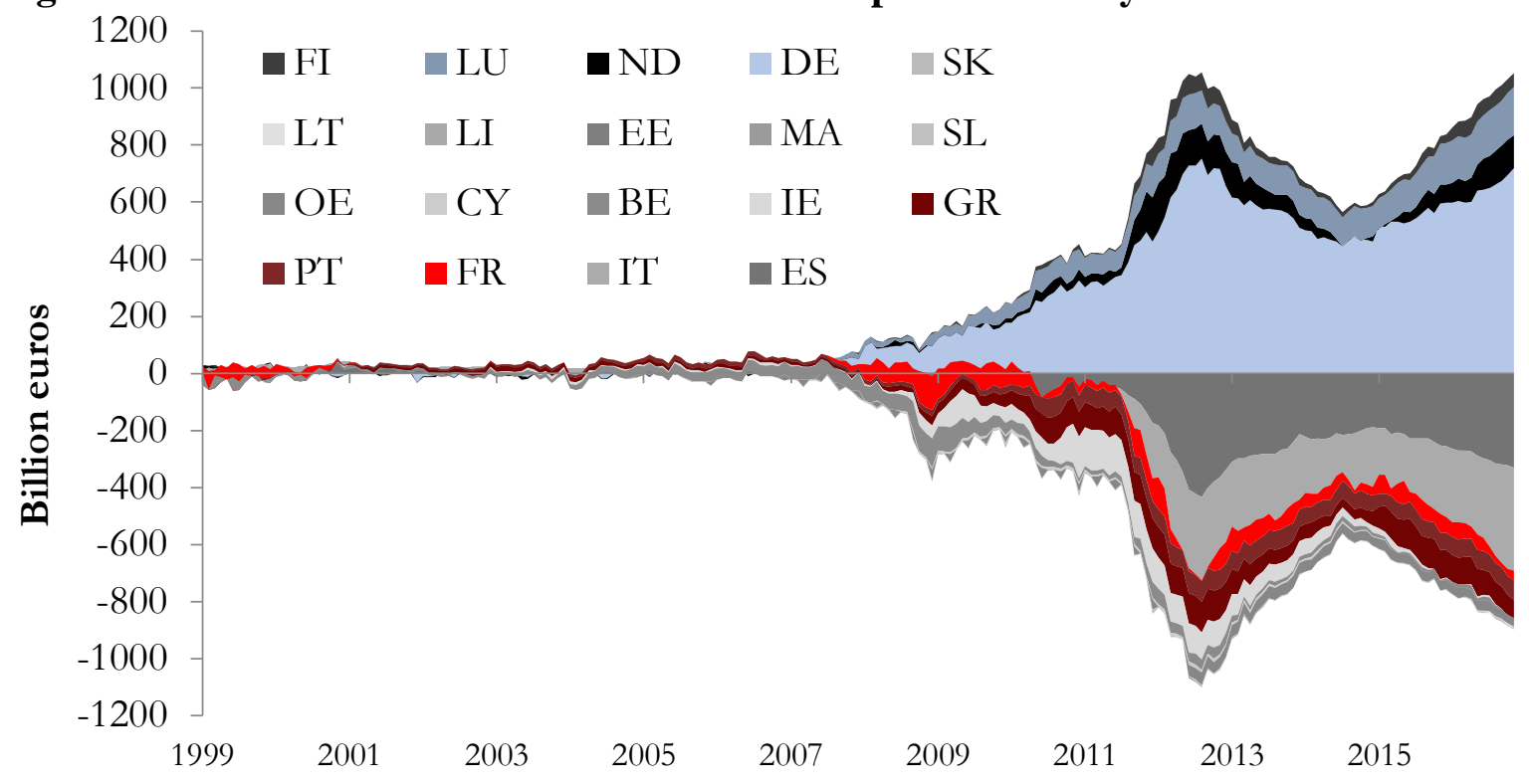

Source: ECB.

Firstly, the end of the overinvestment boom and the necessary dismantling of low return investment projects, creates bad loans. The stock of these (potential) bad loans is reduced by the monetary policy rescue measures, but the monetary policy rescue measures depress the spread between lending and deposit rates as the traditional source of income of banks. ${ }^{16}$ Secondly, the credit volume shrinks, because supply and demand for credit are contracting. In particular, for large companies - which can issue their own securities and stocks - financing costs and thereby the need for bank credit drop. ${ }^{17}$ In contrast to large enterprises, small and medium enterprises profit less from the low-cost liquidity provision, as they remain dependent on the ailing banking sector. Although the creeping stagnation beclouds their profit opportunities, banks will prolong credit lines to shaky small and medium enterprises, because they fear their (potential) bad loan problem to worsen or to become visible.

16 In addition, the low-interest rate and the unconventional monetary policy measures depress the margin between long-term and short-term interest rates (transformation margin). Furthermore, the margin between the money market rate and the deposits rate is pushed towards zero.

17 The declining financing costs of enterprises become visible in growing enterprise savings, which has for instance turned positive in Japan and Germany. The rise in enterprise savings corresponds to a decline in household savings. It is difficult to provide empirical evidence for the hypothesis of a global liquidity glut as launched by Bernanke (2005), because the assumed structural increase in net household savings of aging societies cannot be observed in any of the ageing countries with surplus savings such as Germany, Japan and China. Instead of in fixed capital formation large enterprises tend invest in financial or real estate markets, where central banks provide a quasi-insurance mechanism against losses. (Increasingly) own shares are bought back, because alternative investment categories (bank deposits, government bonds) render low yields due to the asymmetric monetary policy crisis management. 
As enterprises can expect that low-cost liquidity provision will persist independent from the profitability, the efforts to strive for innovation and productivity increases are subdued. For Japan - where the (close to) zero interest rate period continues since the mid 1990s - Sekine, Kobayashi and Saita (2003) find forbearance lending: Banks continue to provide irrecoverable loans to keep themselves and (potentially) insolvent enterprises alive. Peek and Rosengren (2005) associate Japan's central bank crisis management with a misallocation of capital, which makes survive companies with poor profit prospects (which they call "evergreening"). Caballero, Hoshi and Kashyap (2008) show that - given the central bank's low-cost credit provision via zombie banks - zombie enterprises become dependent on cheap liquidity provision, with productivity increases declining. ${ }^{18}$

In the monetary overinvestment theories by Mises (1912) and Hayek (1929) too favorable refinancing conditions during the upswing trigger additional investment projects with lower expected returns. The marginal and average efficiency of investments decreases. During downturn and crisis, investment projects with low internal interest rates are dismantled. The marginal and average efficiency of investments increases. Therefore, in the long term the average efficiency of investment is mainly constant. With the asymmetric monetary policy crisis management of the European Central Bank, however, the average marginal efficiency of investments declines during the boom and remains low, because enterprises with low expected returns are kept alive. ${ }^{19}$

Because resources remain bound in investment projects with low productivity, private investment is affected negatively. The financing of new (i.e. risky) investment is discouraged because monetary policy crisis management damages the banking sector (see above). Furthermore, as the European Central Bank's crisis management prevents asset prices in crisis countries from further falling and drives up other asset prices (such as German stock and real estate prices), there is an incentive to substitute fixed capital investment by speculation in the financial markets. As shown in the upper panel of Figure 10, since the outbreak of the European financial and crisis in the crisis countries investment as a share of GDP has dramatically declined. As currently asset prices rise more in Germany than in the crisis countries, capital

18 Kornai (1993) characterized the situation in the central and eastern European economies before 1990 as soft budget constraints: unprofitable enterprises were kept alive by credit provision of the state-owned banking sector to avoid unemployment. As savings at state-owned banks were not large enough to cover the financing needs of enterprises, the funds were created by the central bank via the printing press.

19 This interpretation is line with Borio (2014), who identifies capital overhang as a major determinant of postbubble crisis. 
flight from the crisis countries to Germany is the logical consequence. As the ample low-cost liquidity provision transforms the financial crisis into a structural crisis in which there is no limit to the central bank's government bond purchases, private investments tend to be gradually substituted by public investments and/or government consumption. Persistently high or even growing government expenditure (as share of GDP) is financed by the government bond purchases of the European Central Bank.

Long-term growth declines, because the ECB`s monetary policy rescue measures slow down productivity gains. In the neoclassical growth theory, growth is dependent on the accumulation of capital. There is a long-term equilibrium between investment and depreciation (steady-state economy). The steady state is derived from the assumption that the marginal efficiency of capital declines with a growing capital stock (Solow 1956). ${ }^{20}$ Long-term growth is generated by innovation and technological progress - i.e. increasing productivity - (Solow 1957).

Leibenstein (1966) saw motivation and incentives as important determinant of a concept of efficiency which goes beyond allocative efficiency ${ }^{21}$. If the degree of competition declines (for instance in a monopoly compared to perfect competition), the motivation to strive for efficiency gains declines as well (X-inefficiency). In this sense, enterprises do not realize a maximum of efficiency gains when the European Central Bank subdues competitive pressure with low-cost liquidity provision. ${ }^{22}$ Competition as a discovery procedure (Hayek 1968) is undermined.

By tying resources to sectors with low or negative productivity gains, in the context of the Solow model the monetary policy rescue measures create a negative allocative effect which results from declining average productivity (defined as output per unit of labor). At the macroeconomic level, with a constant amount of labor fewer goods and services are produced. Declining or even negative productivity growth implies declining real wage increases or even declining real wage levels, which signal lower consumption in the future. If enterprises anticipate declining demand in the future, they reduce investment. A downward spiral of declining investment, growth and consumption sets in.

\footnotetext{
20 This assumption is also made by Summers (2014), who argues that the structural decline of growth is due to a global savings glut combined with a declining marginal efficiency of investment. See also Laubach and Williams (2015) for a demand-driven definition of the natural interest rate.

21 Which assumes constant production costs in different types of markets.

22 Borio et al. (2016) show the negative impact of credit booms on the allocation of labor and productivity gains.
} 


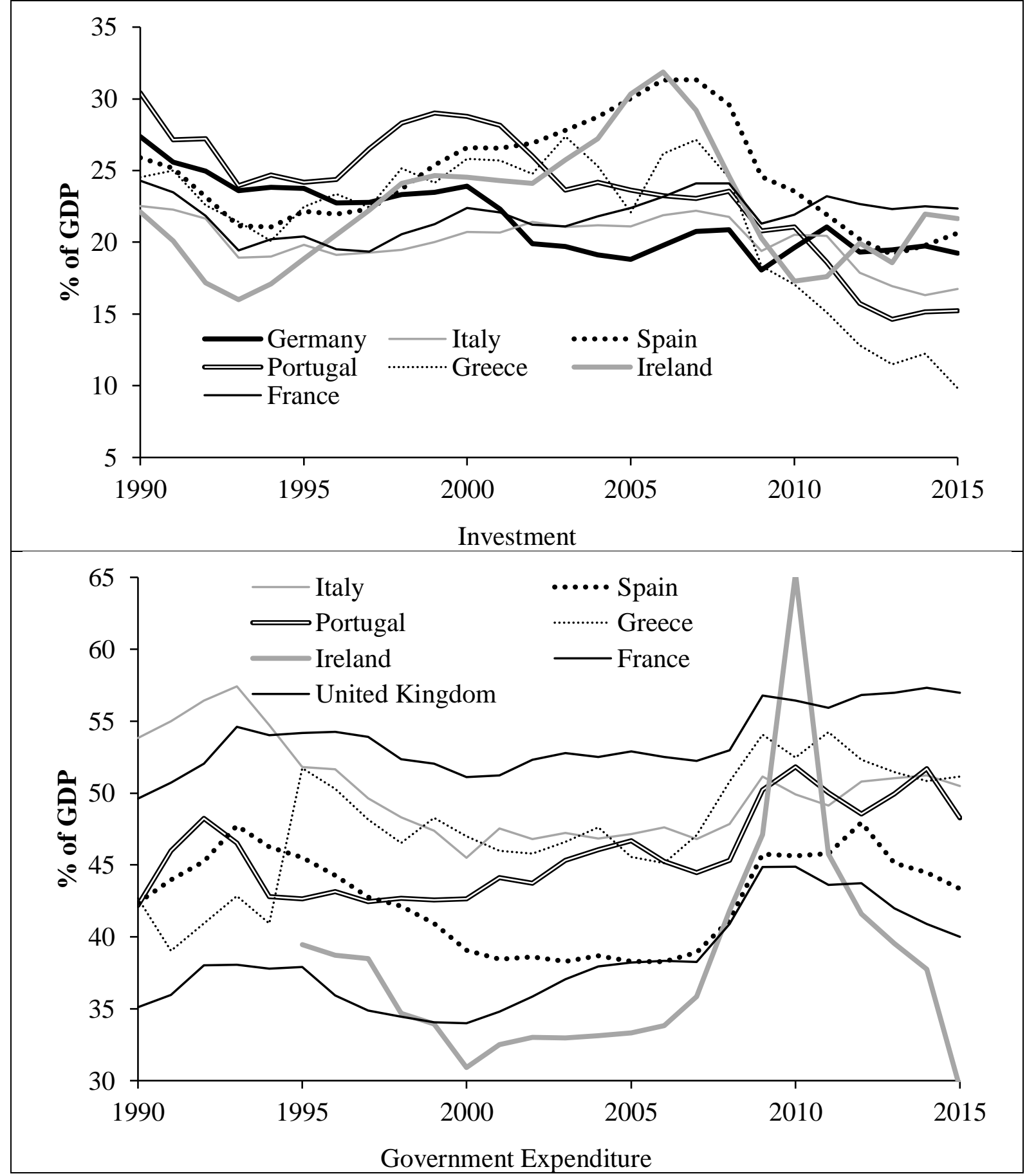

Source: IMF.

The upshot is that low cost liquidity provision of the European Central Bank to the crisis countries via unconventional monetary policy, Emergency Liquidity Assistance, rescue packages and government bond purchases (which are all reflected in TARGET2 balances) conserves inefficient economic structures in the European crisis countries. Extensive purchases of government bonds allow governments to maintain inefficient expenditure patterns by postponing structural reforms. Gopinath et al. (2015) show empirically that the southern 
European crisis countries have experienced since the outbreak of the European debt and financial crisis a significant drop in productivity growth. As growth in these crisis countries does not pick up, this further necessitates the extension of the central bank-centered rescue measures.

\section{4b. Speculative Upswing Inside Germany and Overinvestment Outside Germany}

With monetary policy paralyzing growth perspectives in the crisis countries, capital outflows have accelerated as indicated by growing current account surpluses (Figure 7). Given that public capital inflows into the crisis countries (i.e. the TARGET2 balances) are positive, private net capital outflows from the crisis countries are even higher than the current account surpluses. One target destination of these capital outflows is Germany where growth perspectives have improved because the reform process after the turn of the millennium has strengthened the international competitiveness of the German industry. This implies positive growth perspectives. Furthermore, as German real estate prices did not increase during the pre-crisis boom, they are regarded to have catch-up potential.

With the ECB`s monetary policy rescue measures becoming increasingly focused on the southern European crisis countries, this implies a large likelihood that the European Central Bank has pushed the interest rate level in Germany below the natural interest rate. As shown in Figure 6, the Taylor rule implies that since the year 2010 the main refinancing rate has been substantially too low. The monetary policy stance looks even much looser if the unconventional monetary policy measures are considered. The implied interest rate is 5 percentage points below the target level, which would be justified by the current levels of inflation (which is close to $2 \%$ ) and growth in Germany. This suggests that an overinvestment boom as modelled in the right panel of Figure has set in.

Yet, in contrast to the monetary overinvestment theory investment in Germany remains sluggish (Figure 10). The boom takes mainly place in the real estate and stock markets as shown in Figure 11 in comparison to Spain. Whereas pre-crisis German real estate prices were stable with Spanish real estate prices increasing strongly, now the trend is reversed: Spanish real estate prices remain sluggish, whereas German real estate prices hike. The monetary policy crisis response of the European Central Bank has boosted German real estate prices for three reasons. Firstly, financing conditions for German real estate credit have considerably improved, as the 
European Central Bank has not only pushed money market interest rates towards zero, but has also nudged long-term interest rates to historically low levels.

Figure 11: Stock and Real Estate Markets Compared in Spain and Germany

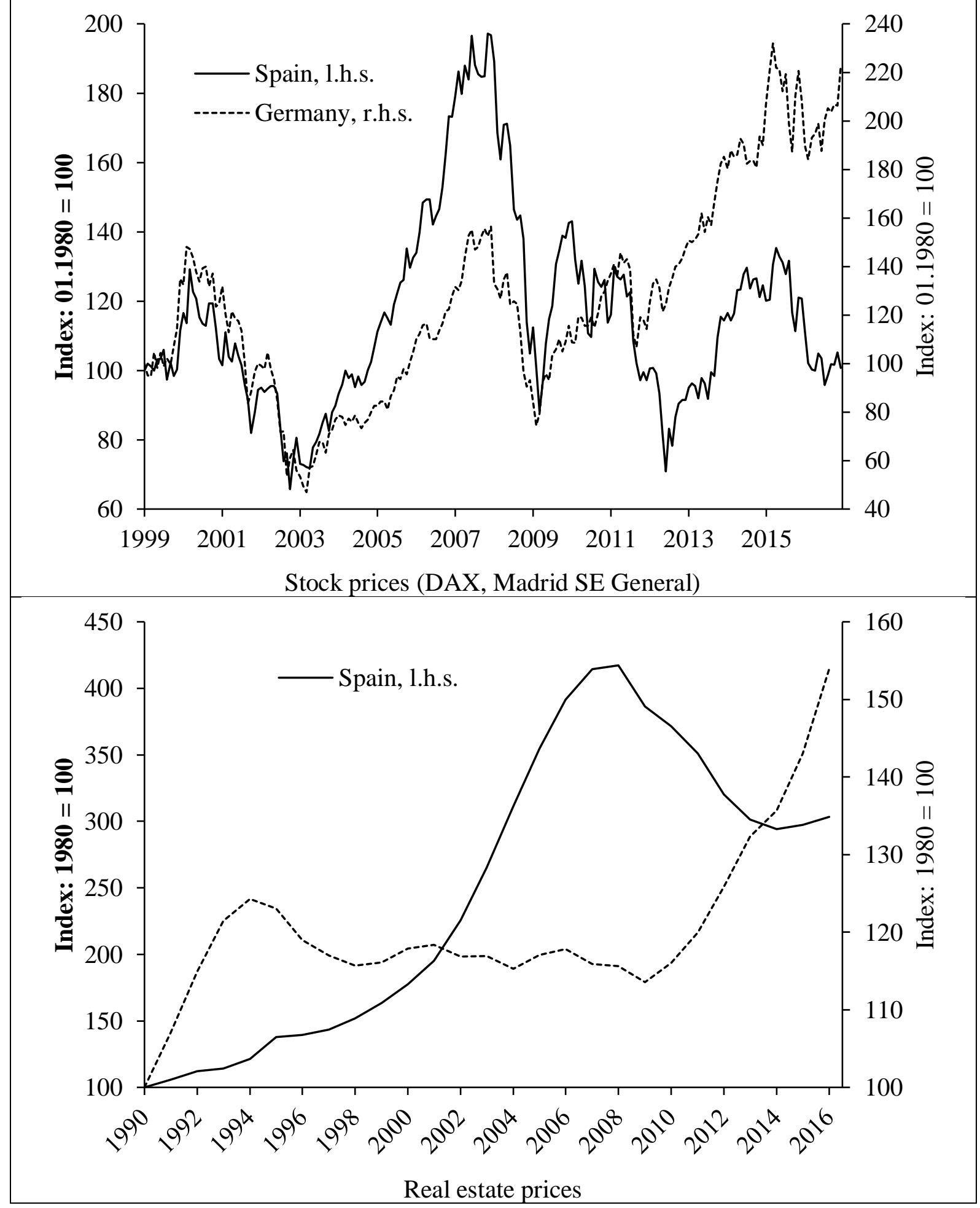

Source: Thompson Reuters Datastream (stock prices), Oxford Economics (real estate prices). 
Secondly, bank deposits have been historically the preferred form of saving in Germany, because inflation has been low. ${ }^{23}$ Given the substantial expansion of the ECB balance sheet, the trust in the stability of money is gradually undermined. With the European Central Bank's monetary policy rescue measures pushing the interest rates of bank deposits toward zero and into negative territory, the inclination to invest in real assets such as estate has increased. Rising price expectations for real estate in Germany's economic centers have pushed up the expected returns despite fast growing prices.

German stock prices are boosted mainly via the export channel. While German industrial enterprises still profit from the past reforms, monetary policy rescue measures of the European Central Bank have created additional windfall profits by depreciating the euro. While the current account surplus still continues to grow (Figure 7), the structure has changed. Because of the tightening of fiscal controls ${ }^{24}$ in the southern and western euro area countries, current account deficits have disappeared or even turned positive. The German trade surplus versus the crisis countries has substantially declined (Figure 12). The post-crisis German fiscal expansion (see Figure 6), which is triggered by growing tax revenues, ${ }^{25}$ is, however, not sufficiently large to reduce the German current account surplus. Therefore, the trade surplus is redirected towards third countries outside the European Monetary Union.

Because the German stock index DAX is dominated by large export-oriented enterprises, the index has strongly pointed upwards (upper panel of Figure 11). German overinvestment is taking place on the back of capital exports to other parts of the world, in particular to the United States and the United Kingdom. The bilateral trade balances of Germany, which can be seen as proxy for bilateral capital flows ${ }^{26}$, as shown in Figure 12 provide respective evidence. The main determinants of growing net capital exports against the United States and the United Kingdom are the relatively loose (tight) monetary policy of the ECB (Fed, Bank of England) combined

23 Therefore, the share of Germans living in their own flat or house is small compared to southern European countries, where inflation has been traditionally high.

24 On details see Belke, Gros and Schnabl (2016).

25 Like in the current crisis countries prior to the crisis, the bubble in Germany currently inflates tax revenues.

26 Positive trade balances are seen as proxy for net capital exports. 
with the relatively tight fiscal policy stance of Germany (versus US and UK). ${ }^{27}$ One important capital export channel seems to be mergers and acquisitions.

It has to be seen, if German investment abroad will turn out as over- or malinvestment in the future (as in many cases in the past ${ }^{28}$ ). The monetary overinvestment theories suggest that the likelihood of overinvestment and speculative bubbles has dramatically increased, as central banks have depressed globally interest rates below the natural interest rate level. This has disturbed the allocation function of the interest rate (which separates investment with high expected returns from investment with low expected returns) and the signaling function of the interest rate (which indicates the risk of default, for instance of over-indebted countries).

Figure 12: Bilateral Trade Balances of Germany

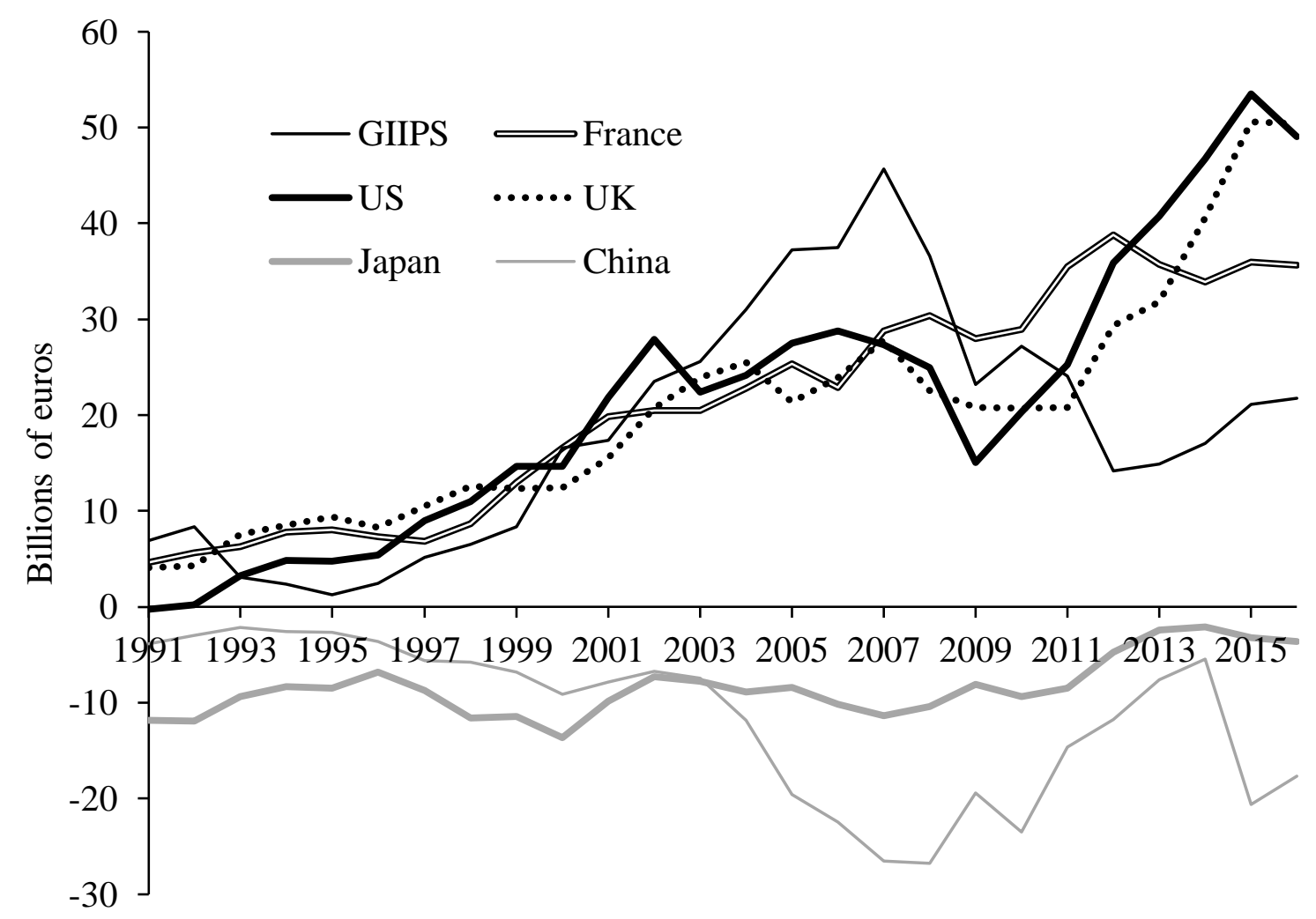

Source: Germany, Statistisches Bundesamt.

27 Because fiscal policies have a direct impact on investment activity, relative fiscal policies stances - in particular in interaction with loose monetary policy stances - constitute an important determinant of current account balances. See Wollmershäuser and Schnabl (2013) for Europe and Duarte and Schnabl (2015) for larger sample of 86 emerging markets and industrialized countries.

28 For instance, German credit provision to the southern and western European countries and to the US subprime boom has turned sour. 
The monetary policy of the European Central Bank is from a Mises-Hayek perspective a failure in several regards. First, the ECB's too loose monetary policy stance is at the roots of the unsustainable investment, real estate and consumption booms in the southern and western euro area countries (and beyond), which have triggered the still lingering European financial and debt crisis (euro crisis). Currently, the ECB`s monetary policy rescue measures, which are fitted to the crisis countries, nurture the build-up of a stock and real estate bubble in Germany. It therefore puts the stage for a future overinvestment and/or financial crisis in the Germany, which only up to the turning point of the cycle will remain the growth engine of Europe.

Secondly, the time-varying emergence of crisis in the different parts of the European Monetary Union is due to a constructional flaw of a heterogeneous monetary union with decentralized fiscal policies. Whereas labor markets in most member states remained rigid, the organization of fiscal policies at a national level has undermined the effectiveness of the common monetary policy. Fiscal policies have not only missed to cure asymmetric shocks in the monetary union, they have even caused asymmetric economic development! In the face of a too loose monetary policy, economic upswings have taken the form of unsustainable overinvestment booms and (have) thereby become the pre-step for severe crisis. The Maastricht fiscal criteria have failed and fail to indicate excessive spending during the speculative upswings as unsustainable tax revenues were/are produced. During the inevitable crisis, hiking government debt levels in the crisis countries are simply a catch-up process for proliferating spending during the pre-crisis exuberance.

Thirdly, the attempts of the European Central Bank to cure the European financial and debt crisis with zero and negative interest rates as well as with extensive government bond purchases has paralyzed investment and growth in all parts of the European Monetary Union. In the southern European crisis countries, distorted economic structures with a low marginal efficiency of investment are conserved, which constitutes an impediment for a sustainable economic recovery. Also in Germany investment activity has not picked up domestically, but has become tilted towards outside the European Monetary Union, in particular to the United States and the United Kingdom. The reason is that ECB's monetary policy rescue measures in combination with relatively tight fiscal policies stimulate capital outflows, i.e. capital flight. 
Given the global low interest rate environment, foreign investment has a large likelihood to be mal-investment and therefore to be a quasi-transfer in favor of the debtor countries.

Forth, because the low-cost liquidity provision of the European Central Bank paralyzes productivity gains and growth in the European Monetary Union, while at the same time having redistribution effects, redistribution conflicts within the euro area have emerged and are likely to further intensify. This is the case within every single euro area member state, because the monetary policy rescue measures redistribute via asset markets in favor of the rich (at the cost of the middle class) and in favor of the older generations (at the cost of the younger generations). ${ }^{29}$ Furthermore, at a supranational level, the TARGET2 system redistributes from Germany, Luxemburg, Finland and the Netherlands to a larger number of euro area countries, which are more or less strongly in crisis mode. The large number of the recipient countries of the TARGET2 quasi-transfer mechanism explains the political acceptability of the monetary policy rescue measures in the board of the ECB.

The negative growth and redistribution effects of the monetary policy rescue measures are likely to become in the long term the stepping stone for the European Monetary Union and the European integration process as a whole. As the TARGET2 balances are equivalent to a transfer of wealth from the donor to the recipient countries, an exit of the donor countries from the European Monetary Union is getting more likely in the course of time. The likelihood will strongly increase, after the overinvestment/speculation boom in Germany has ended. Because the monetary policy rescue measures paralyze growth and lead to growing inequality, eurocritical parties questioning the European integration process are already growing in merely all European countries.

The logical political reflex to declining growth and spreading frustration among the population is economic nationalism (see Hayek 1944), which endangers the four freedoms as the fundament of wealth and political cohesion in Europe. This should be reason enough to terminate the ultra-loose monetary policy rescue measures soon. Government bond purchases of the European Central Bank should be ended at once. The main refinancing rate should be lifted slowly, but decisively to prompt a gradual adjustment of banks, enterprises and governments to the reconstitution of the allocation and signaling function of the interest rate. Only a tightening of monetary policy will lead to a revival of productivity gains and thereby a

\footnotetext{
${ }^{29}$ For details see Hoffmann and Schnabl (2016).
} 
recovery of growth, which is the basis for real wage increases all over Europe. Only if market principles are restored, the fundament for integration, wealth, cohesion and peace in Europe will be reconstituted.

\section{References}

Adrian, Tobias / Shin, Hyun Song (2008): Liquidity, Monetary Policy and Financial Cycles. Current Issues in Economics and Finance 14, 1.

Baur, Dirk / Gerstenberger, Juliane / Schnabl, Gunther (2017): A Structural Break in Monetary Policy Transmission. Mimeo.

Belke, Ansgar / Gros, Daniel / Schnabl, Gunther (2016): Das europäische Verfahren zur Vermeidung und Korrektur makroökonomischer Ungleichgewichte - Eine Forschungsagenda zu Reformansätzen. Wirtschaftsdienst 96, 8, 548-556.

Bernanke, Ben (2005): The Global Saving Glut and the U.S. Current Account Deficit. Remarks at the Sandridge Lecture, Virginia Association of Economists, Richmond, Virginia.

Bernanke, Ben (2014): The Federal Reserve: Looking Back, Looking Forward. Speech at the Annual Meeting of the American Economic Association, Philadelphia, 3 January 2014.

Blinder, Alan / Reis, Ricardo (2005): Understanding the Greenspan Standard. Princeton University Department of Economics Working Papers 88.

Borio, Claudio (2014): The Financial Cycle and Macroeconomics: What Have We Learnt? Journal of Banking and Finance 45, 182-198.

Borio, Claudio / Kharroubi, Enisse / Upper, Christian / Zampolli, Fabrizio (2016): Labour Reallocation and Productivity Dynamics: Financial Causes, Real Consequences. BIS Working Papers 534.

Brunnermeier, Markus / Schnabel, Isabel (2014): Bubbles and Central Banks: Historical Perspectives. Mimeo.

Caballero, Ricardo / Hoshi, Takeo, / Kashyap, Anil (2008): Zombie Lending and Depressed Restructuring in Japan. American Economic Review 98, 5, 1943-1977.

De Grauwe, Paul (2011): Monetary Policy and Animal Spirits. Economic Theory 47, 2-3, 423457.

De Grauwe, Paul (2016): The Economic of Monetary Union. Oxford: Oxford University Press.

Draghi, Mario (2014): The Path to Recovery and the ECB's Role. Speech by Mario Draghi, President of the ECB, at the Symposium on Financial Stability and the Role of Central Banks organised by the Deutsche Bundesbank, Frankfurt am Main, 27 February 2014. 
Duarte, Pablo / Schnabl, Gunther (2015): Macroeconomic Policy Making, Exchange Rate Adjustment and Current Accounts in Emerging Markets. Review of Development Economics $19,3,531-544$.

Gopinath, Gita / Kalemli-Özkan, Şebnem / Karabarbounis, Loukas / Villegas-Sanchez, Carolina (2015): Capital Allocation and Productivity in South Europe. Mimeo.

Freytag, Andreas / Schnabl, Gunther 2017: Monetary Policy Crisis Management as a Threat to Economic Order. Forthcoming as CESifo Working Paper.

Hayek, Friedrich August von (1929): Geldtheorie und Konjunkturtheorie, Salzburg, Philosophia Verlag.

Hayek, Friedrich August von (1931): Prices and Production. New York, August M. Kelly Publishers.

Hayek, Friedrich August von (1933): Monetary Theory and the Trade Cycle. London: Jonathan Cape.

Hayek, Friedrich August von (1937 [1989]): Monetary Nationalism and International Stability, Augustus Kelley Publishers, Fairfield, New Jersey.

Hayek, Friedrich August von (1944): The Road to Serfdom, Routledge, London.

Hayek, Friedrich August von (1968): Der Wettbewerb als Entdeckungsverfahren. In: Internationales Institut „Österreichische Schule der Nationalökonomie" (Hrsg.): Die Österreichische Schule der Nationalökonomie. Texte - Band II von Hayek bis White. Wien: Manz'sche Verlags- und Universitätsbuchhandlung, 119-137.

Hoffmann, Andreas / Schnabl, Gunther (2008): Monetary Policy, Vagabonding Liquidity and Bursting Bubbles in New and Emerging Markets - An Overinvestment View. The World Economy 31, 1226-1252.

Hoffmann, Andreas / Schnabl, Gunther (2011): A Vicious Cycle of Manias, Crises and Asymmetric Policy Responses - An Overinvestment View. The World Economy 34, 382403.

Hoffmann, Andreas / Schnabl, Gunther (2014): Monetary Policy in Large Industrialized Countries, Emerging Market Credit Cycles, and Feedback Effects. CESifo Working Paper 4723.

Hoffmann, Andreas / Schnabl, Gunther (2016): The Adverse Effects of Unconventional Monetary Policy. Together with Andreas Hoffmann. Cato Journal 36, 3, 449-484.

Keynes, John Maynard (1936): The General Theory of Employment, Interest, and Money, Cambridge, Macmillan Cambridge University Press.

Kornai, János (1986): The Soft Budget Constraint. Kyklos 39 1, 3-30.

Laubach, Thomas / Williams, John (2015): Measuring the Natural Rate of Interest Redux. Federal Reserve Bank of San Francisco Working Paper 2015-16. 
Mises, Ludwig von (1912): Die Theorie des Geldes und der Umlaufmittel, Duncker und Humblot, Leipzig.

Mundell, Robert (1961): A Theory of Optimum Currency Areas. American Economic Review $51,4,657-665$.

Peek, Joe / Rosengren, Eric (2005): Unnatural Selection: Perverse Incentives and the Misallocation of Credit in Japan. American Economic Review 95, 4, 1144-1166.

Schnabl, Gunther (2015): Monetary Policy and Structural Decline: Lessons from Japan for the European Crisis. Asian Economic Papers 14, 1, 124-150.

Schumpeter, Joseph (1912): The Theory of Economic Development, Cambridge, Massachussetts.

Sekine, Toshitaka / Kobayashi, Keiichiro / Saita, Yumi (2003): Forbearance Lending: The Case of Japanese Firms. Bank of Japan Institute for Monetary and Economic Studies 21, 2, 6992.

Sinn, Hans-Werner / Wollmershäuser, Timo 2012: Target Loans, Current Account Balances and Capital Flows: The ECB's Rescue Facility. International Tax and Public Finance 19, 4, 468-508.

Solow, Robert (1956): A Contribution to the Theory of Economic Growth. Quarterly Journal of Economics 70, 1, 65-94.

Solow, Robert (1957): Technical Change and the Aggregate Production Function. Review of Economics and Statistics 39, 2, 312-320.

Summers, Larry (2014): U.S. Economic Prospects: Secular Stagnation, Hysteresis, and the Zero Lower Bound. Business Economics 49, 2, 65-73.

Taylor, John (1993): Discretion versus Policy Rules in Practice. Carnegie-Rochester Conference Series on Public Policy 39, 195-214.

Wollmershäuser, Timo / Schnabl, Gunther 2013: Fiscal Divergence and Current Account Imbalances in Europe. CESifo Working Paper 4108.

Wicksell, Knut (1898): Geldzins und Güterpreise, FinanzBuch Verlag, München. 